\title{
Equipment
}

\author{
Markus Weiss MD, * \\ Maja I. Hug MD, $†$ \\ Thomas Neff MD, * \\ Joachim Fischer MD MS $\dagger$
}

\section{Syringe size and flow rate affect drug delivery from syringe pumps}

Purpose: To evaluate the effect of syringe size and infusion rate on drug delivery after vertical displacement of syringe pumps.

Methods: Four syringes ( $10 \mathrm{ml}, 20 \mathrm{ml}, 30 \mathrm{ml}, 50 \mathrm{ml})$ were studied at three infusion speeds $\left(2 \mathrm{ml} \cdot \mathrm{hr}^{-1}, \mathrm{I} \mathrm{ml} \cdot \mathrm{hr}^{-1}\right.$ and $0.5 \mathrm{ml} \cdot \mathrm{hr}^{-1}$ ). Fluid delivery was measured gravimetrically using an electronic balance. Aspiration volume (amount of fluid retracted into the syringe-infusion line assembly) and zero-drug delivery time (time between the lowering of the syringe pump and reattainment of the initial weight) were determined after lowering the syringe pump $130 \mathrm{~cm}$ or $50 \mathrm{~cm}$. Then, infusion bolus was measured after elevating the pump to its initial position. Syringe compliance was calculated from the occlusion release bolus at an occlusion pressure of $300 \mathrm{mmHg}$.

Results: Zero-drug delivery time, aspiration volume and infusion bolus increased with syringe size $(P<0.000 \mathrm{I})$. At $0.5 \mathrm{ml} \cdot \mathrm{hr}^{-1}$, a zero-drug delivery time of $29.7 \pm 0.6 \mathrm{~min}$ was recorded for the $50 \mathrm{ml}$ syringe and $5.5 \pm 0.15$ $\mathrm{min}$ for the $10 \mathrm{ml}$ syringe. As infusion rates increased, zero-drug delivery times decreased following a $\mathrm{I} / \mathrm{x}$ ratio. Zero-drug delivery time highly correlated with calculated syringe compliance (Pearson's $r=0.97, P<0.00 \mathrm{I}$ ), which was closely related to syringe plunger area $\left(R^{2}=0.93, P<0.00 \mathrm{I}\right)$.

Conclusions: Vertical displacement of syringe pumps causes flow irregularities which correlate directly with syringe size and indirectly with infusion rate. Extreme vertical maneuvering of syringe pumps should be avoided. Infusion rates $\geq 1 \mathrm{ml} \cdot \mathrm{hr}^{-1}$ and low-compliant, small syringes are recommended when highly concentrated drugs are administered.

Objectif: Évaluer l'effet de la taille de la seringue et de la vitesse de perfusion sur l'administration de médicament après le déplacement vertical de la pompe à perfusion.

Méthode : Quatre seringues ( $10 \mathrm{ml}, 20 \mathrm{ml}, 30 \mathrm{ml}, 50 \mathrm{ml}$ ) ont été étudiées pour trois vitesses de perfusion (2 $\mathrm{ml} \cdot \mathrm{h}^{-1}, \mathrm{I} \mathrm{ml} \cdot \mathrm{h}^{-1}$ et $\left.0,5 \mathrm{ml} \cdot \mathrm{h}^{-1}\right)$. Une mesure gravimétrique de l'administration du liquide a été faite avec une balance électronique. Le volume d'aspiration (quantité de liquide rétracté dans l'ensemble tubulure-seringue) et la durée de non-perfusion (temps entre le moment où on abaisse la pompe et le moment où on retrouve le poids initial) ont été déterminés après avoir baissé la pompe de $130 \mathrm{~cm}$ ou $50 \mathrm{~cm}$. Puis, le bolus de perfusion a été mesuré après le retour de la pompe à sa position initiale. La compliance de la seringue a été calculée à partir du passage du bolus jusqu'à une pression d'occlusion de $300 \mathrm{mmHg}$.

Résultats : La durée de non-perfusion, le volume d'aspiration et le bolus de perfusion ont augmenté avec la taille de la seringue $(P<0,000 \mathrm{I})$. À $0,5 \mathrm{ml} \cdot h^{-1}$, la durée de non-perfusion a été de 29,7 $\pm 0,6$ min pour la seringue de $50 \mathrm{ml}$ et de $5,5 \pm 0,15 \mathrm{~min}$ pour celle de $10 \mathrm{ml}$. À mesure que les vitesses de perfusion augmentent, la durée de non-perfusion diminue selon un ratio de $1 / x$. La durée de non-perfusion présentait une forte corrélation avec la compliance calculée de la seringue (Pearson's $r=0,97, P<0,00 \mathrm{I}$ ), compliance qui était en étroite relation avec l'aire du piston de seringue $\left(R^{2}=0,93, P<0,00 I\right)$.

Conclusion : Le déplacement vertical de la pompe à perfusion cause des irrégularités d'écoulement qui sont en corrélation directe avec la taille de la seringue et en corrélation indirecte avec la vitesse de perfusion. On doit éviter de déplacer verticalement, et de façon marquée, la pompe à perfusion de façon importante. Cela nous

From the Departments of Anaesthesia* and Intensive Care and Neonatology, $†$ University Children's Hospital, Steinwiesstrasse 75, Zurich - Switzerland.

Address correspondence to: Dr. Markus Weiss. Phone: +41-1-266-71-11; Fax: +41-1-266-71-68; E-mail: markus.weiss@kispi.unizh.ch. Accepted for publication April 2, 2000. 


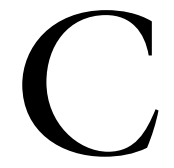

ONTINUOUS intravenous administration of drugs with short half-lives, such as inotropic agents, vasodilators or insulin, by syringe pumps and syringes of $50 \mathrm{ml}$ volume is a standard technique in neonatal and pediatric anesthesia and critical care. In small infants, highly concentrated inotropic or vasoactive drugs are usually delivered using very low infusion rates $(0.5-2$ $\mathrm{ml} \cdot \mathrm{h}^{-1}$ ) to avoid volume overload. Under these conditions small variations of the drug delivery rate can cause serious hemodynamic instability. ${ }^{1-3}$

Variations in drug delivery have been reported following vertical displacement of the syringe pump. ${ }^{4-6}$ They are caused by gravitational siphoning or emptying of fluid into, or from, the syringe. While the free play of the syringe plunger in modern pump drivers seems to be negligible (external compliance), it is likely that the internal compliance of the syringe is mostly responsible for hydrostatic volume redistribution. An earlier report from Rooke and Bowdle suggested that smaller syringes would be less susceptible to the problems of gravity because of lower compliance. ${ }^{4}$

The aim of the study was to explore the influence of syringe size and flow rate on drug delivery after vertical syringe pump displacement using commercially available infusion pump syringes of different sizes and at clinically relevant infusion rates.

\section{Methods}

Four syringes of different volume were used $(10 \mathrm{ml}$, $20 \mathrm{ml}, 30 \mathrm{ml}, 50 \mathrm{ml}$ syringe, BD Plastipak, Becton Dickinson, Meylan Cedex, France). Primary variables of interest were the aspiration volume (the amount of fluid retracted into the syringe-infusion line assembly) and the zero-drug delivery time (the time from low ering of the syringe pump to reattainment of the initial weight on the balance) resulting from lowering the infusion pump by $130 \mathrm{~cm}$ or by $50 \mathrm{~cm}(10 \mathrm{ml}$ and $50 \mathrm{ml}$ syringes only) and the additional infusion bolus after elevating the syringe to its original position.

Each syringe was filled with distilled water and inserted into an IVAC syringe pump (IVAC-Alaris, IVAC Medical Systems, Hampshire, United Kingdom), which allowed use of different sized syringes without free play of the syringe plunger in the syringe pump driver. The syringe was attached to a low-compliant tubing line of $2 \mathrm{~m}$ length (InjectomatLine, Fresenius AG, Bad Homburg, Germany), which was connected to a single lumen central venous catheter (Central Venous Catheterisation Set, 14 Ga. $/ 30 \mathrm{~cm}$, Arrow International Inc, Reading, PA). The catheter was immersed $13 \mathrm{~cm}$ into a sampling glass filled with sterile water to simulate central venous pressure of $10 \mathrm{mmHg}$. The water surface in the glass was covered with a thin layer of oil to avoid fluid evaporation. The whole assembly was flushed and cleared of remaining air bubbles (Figure 1).

The fluid delivery from the central venous catheter tip into the glass was measured gravimetrically by an electronic balance with $0.0001 \mathrm{~g}$ sensitivity (AG 204Delta-Range ${ }^{\circledR}$, Mettler Toledo, Schwerzenbach, Switzerland). ${ }^{7}$ The balance data output was recorded in one second intervals by an IBM-compatible personal computer employing software specifically written for this purpose (MCPS V2.6-CAD, Software $\mathrm{GmbH}$, Mönchengladbach, Germany).

Before starting measurements, the syringe outlet was positioned at the level of the CVC tip. After obtaining steady state flow conditions at the chosen infusion rate $\left(0.5 \mathrm{ml} \cdot \mathrm{hr}^{-1}, 1 \mathrm{ml} \cdot \mathrm{hr}^{-1}\right.$ or $\left.2 \mathrm{ml} \cdot \mathrm{hr}^{-1}\right)$, the syringe pump was vertically displaced to a level of 130 $\mathrm{cm}($ or $50 \mathrm{~cm}$ ) below the tip of the immersed catheter. The resulting aspiration volume and the zero-drug delivery time were recorded. After regaining steady state flow delivery, the pump was returned to its original position. The infusion bolus resulting from relief of hydrostatic pressure was measured. All experiments were repeated five times and were performed at $25^{\circ} \mathrm{C}$ ambient temperature.

To determine syringe compliance, a three-way stopcock attached to a blood pressure transducer by the side port was inserted between the syringe outlet and the infusion line. The stopcock was turned to obstruct syringe outflow until an occlusion pressure of $300 \mathrm{~mm}$ $\mathrm{Hg}$ was reached. After release of the occlusion, the delivered infusion bolus was measured gravimetrically as described above to calculate the compliance. Compliance

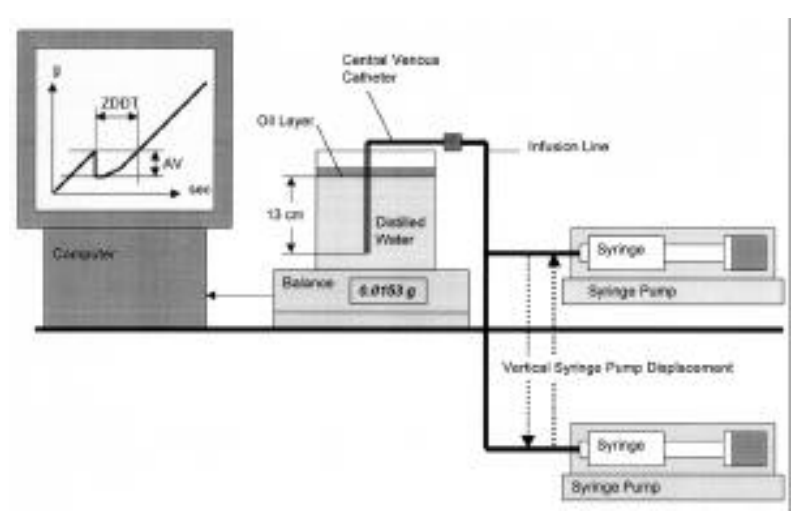

FIGURE 1 Schematic description of the assembly for in vitro measurement of drug delivery from different sized syringes at different infusion rates after lowering and re-elevating the syringe pump by 130 or $50 \mathrm{~cm}$. (ZDDT: zero-drug delivery time; AV: aspiration volume). 


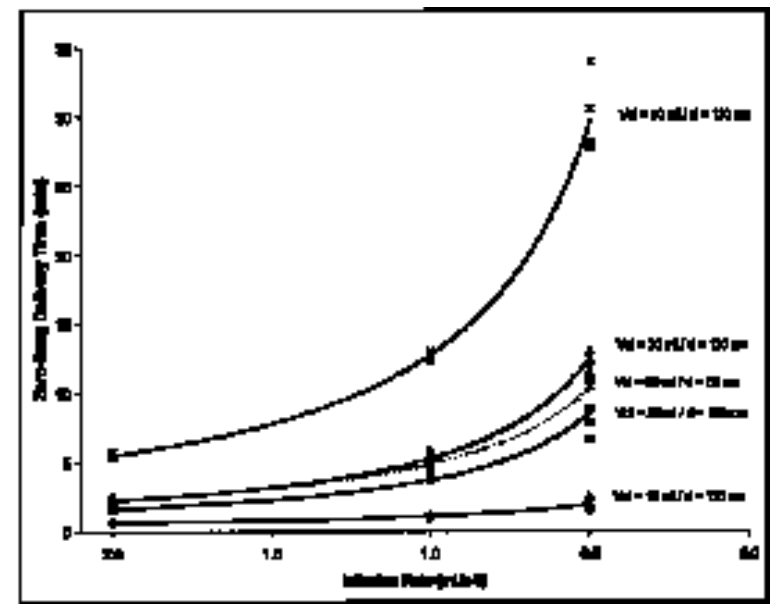

FIGURE 2 Infusion rates (horizontal axis) are shown in relation to zero-drug delivery times (vertical axis). The thick lines represent the regression lines fitted through the observed results (all $\mathrm{R}$ $>0.95$, all $P<0.0001$ ) for vertical displacement by $130 \mathrm{~cm}$ using syringe volumes of $10 \mathrm{ml}, 20 \mathrm{ml}, 30 \mathrm{ml}$ and $50 \mathrm{ml}$. The thin line connects the calculated data points derived from the zero-drug delivery time measured at an infusion rate of $1 \mathrm{ml} \cdot \mathrm{hr}^{-1}$ and a 50 $\mathrm{cm}$ vertical displacement. All measurements were repeated in quintuplicate.

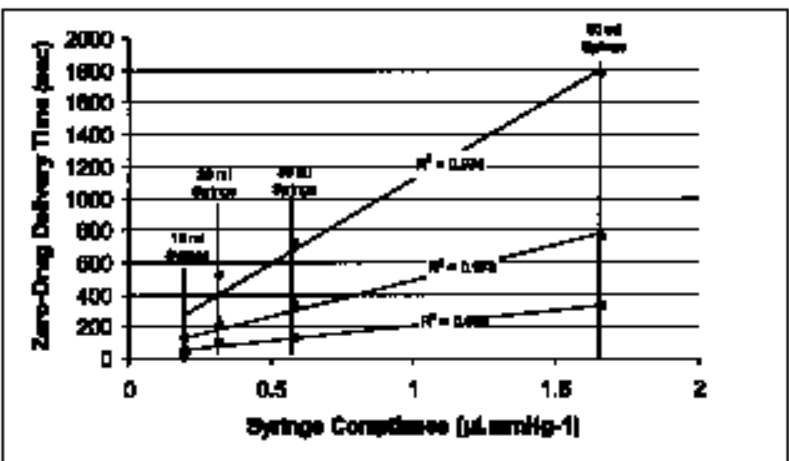

FIGURE 3 Approximated syringe compliance (horizontal axis) is shown in relation to zero-drug delivery time (vertical axis) at infusion rates of $0.5 \mathrm{ml} \cdot \mathrm{hr}^{-1}(\bullet) 1.0 \mathrm{ml} \cdot \mathrm{hr}^{-1}(\mathbf{\Delta})$ and $2.0 \mathrm{ml} \cdot \mathrm{hr}^{-1}$ after lowering the syringe pump by $130 \mathrm{~cm}$.

results are approximated because they include the small, but unknown, additional compliance contributed by the pressure transducer and the syringe pump.

Aspiration volume, zero-drug delivery time and infusion bolus were compared across syringes and infusion rates by means of two-way analysis of vari-

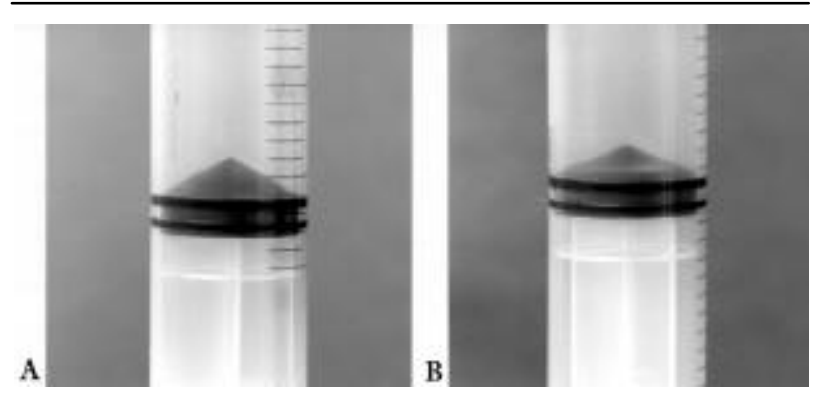

FIGURE 4 Plunger of a 50-ml syringe at zero pressure (Panel A) and at an occlusion pressure of $300 \mathrm{~mm} \mathrm{Hg}$ (Panel B). Panel B illustrates that a major source of the internal syringe compliance is the compression of the rubber seal of the syringe plunger.

ance, with syringe size and infusion rates as the two factors. Post-hoc tests were carried out using Scheffe's correction for multiple testing. Both linear and quadratic regression equations were fitted to investigate the relation between observed zero-drug delivery time and measured syringe compliance. A $P$ value of $<0.05$ was considered statistically significant. All analyses were performed using the Statistical Analysis Software (SAS Version 6.12, SAS Inc., Cary, NC).

Results

The zero-drug delivery time, the size of the aspiration bolus and the infusion bolus caused by a vertical displacement of the syringe pump increased with syringe size (all $\mathrm{F}>181.0, \mathrm{dF}=11 / 48$, all $\mathrm{R}^{2}>0.95$, all $P<$ $0.0001)$. At infusion rates of $0.5 \mathrm{ml} \cdot \mathrm{hr}^{-1}$, long zerodrug delivery times of up to $29.7 \pm 0.6 \mathrm{~min}$ were recorded for the $50 \mathrm{ml}$ syringe compared with $5.5 \pm$ $0.15 \mathrm{~min}$ for the $10 \mathrm{ml}$ syringe (Figure 2). As infusion rates increased, zero drug delivery times rapidly decreased following a $1 / x$ ratio (e.g. doubling the infusion rate halves the zero-drug delivery time). The amount of vertical displacement showed a linear correlation with the duration of zero-drug delivery time, aspiration volume and infusion bolus (linear regression, all $\left.\mathrm{R}^{2}>0.98, P<0.0001\right)$. In contrast to the zero-drug delivery time, aspiration volume and infusion bolus were not related to the infusion rate (ANOVA, $P=0.07$ ) but showed a close relation to syringe volume (linear regression $R^{2}=0.92$, quadratic regression $\left.\mathrm{R}^{2}=0.98, P<0.0001\right)$. Data are compared across syringe sizes in the Table.

Syringe size compliance determined by the occlusion release bolus and zero-drug delivery times showed an almost linear correlation at all infusion 
TAB LE Data measured during vertical infusion pump displacement (results in mean \pm SEM; two-way-ANOVA, $P<0.001$ ).

\begin{tabular}{|c|c|c|c|c|c|c|c|}
\hline \multirow{2}{*}{$\begin{array}{l}\text { Syringe Size } \\
\text { Displacemen }\end{array}$} & \multirow{2}{*}{$\begin{array}{l}\text { Flow Rate } \\
\mathrm{ml} \cdot \mathrm{hr} r^{-1}\end{array}$} & \multicolumn{2}{|c|}{$\begin{array}{l}\text { Zero-Drug Delivery Time } \\
\text { min }\end{array}$} & \multicolumn{2}{|c|}{$\begin{array}{l}\text { Aspiration Bolus } \\
m l\end{array}$} & \multicolumn{2}{|c|}{$\begin{array}{l}\text { Infusion Bolus } \\
m l\end{array}$} \\
\hline & & & & & & & \\
\hline \multirow[t]{3}{*}{$10 \mathrm{ml}$} & 0.5 & 2.1 & \pm 0.4 & 0.008 & \pm 0.003 & 0.01 & \pm 0.003 \\
\hline & 1.0 & 1.1 & \pm 0.08 & 0.01 & \pm 0.003 & 0.02 & \pm 0.003 \\
\hline & 2.0 & 0.61 & \pm 0.05 & 0.01 & \pm 0.003 & 0.02 & \pm 0.003 \\
\hline \multirow[t]{3}{*}{$20 \mathrm{ml}$} & 0.5 & 8.7 & \pm 1.1 & 0.028 & \pm 0.003 & 0.042 & \pm 0.003 \\
\hline & 1.0 & 3.8 & \pm 0.9 & 0.026 & \pm 0.005 & 0.042 & \pm 0.003 \\
\hline & 2.0 & 1.6 & \pm 0.05 & 0.022 & \pm 0.003 & 0.042 & \pm 0.003 \\
\hline \multirow[t]{3}{*}{$30 \mathrm{ml}$} & 0.5 & 21.1 & \pm 0.6 & 0.04 & \pm 0.003 & 0.056 & \pm 0.005 \\
\hline & 1.0 & 5.6 & \pm 0.16 & 0.04 & \pm 0.003 & 0.05 & \pm 0.004 \\
\hline & 2.0 & 2.2 & \pm 0.2 & 0.03 & \pm 0.003 & 0.05 & \pm 0.005 \\
\hline \multirow[t]{3}{*}{$50 \mathrm{ml}$} & 0.5 & 29.7 & \pm 2.1 & 0.078 & \pm 0.0064 & 0.158 & \pm 0.0064 \\
\hline & 1.0 & 12.8 & \pm 0.2 & 0.068 & \pm 0.0032 & 0.166 & \pm 0.0048 \\
\hline & 2.0 & 5.5 & \pm 0.15 & 0.062 & \pm 0.0032 & 0.16 & \pm 0.0048 \\
\hline \multicolumn{8}{|c|}{ Displacement by $50 \mathrm{~cm}$} \\
\hline $10 \mathrm{ml}$ & 1.0 & 0.4 & \pm 0.05 & 0.003 & \pm 0.001 & 0.004 & \pm 0.001 \\
\hline $50 \mathrm{ml}$ & 1.0 & 5.1 & \pm 0.16 & 0.021 & \pm 0.003 & 0.04 & \pm 0.003 \\
\hline
\end{tabular}

rates $(0.5 \mathrm{ml} / \mathrm{h}:$ Pearson's $\mathrm{r}=0.97, P<0.001$ Figure 3). Geometrical measurements of the syringes revealed a close relation between syringe compliance and area of the rubber seal of the syringe plunger (linear regression $\left.\mathrm{R}^{2}=0.93, P<0.001\right)$.

\section{Discussion}

The effect of syringe size on the performance of an infusion pump regarding accuracy of infusion delivery, time to occlusion alarm and size of occlusion release bolus was recently reported by Kim and Steward. ${ }^{8}$ The use of a larger syringe size was found not to affect the accuracy of infusate delivery, but to delay the time to occlusion alarm and to increase the size of occlusion release bolus. However, the influence of syringe size at different infusion rates on drug delivery after vertical displacement of a syringe pump has not been previously documented. Our findings confirm the suggestion that increased flow irregularities result from larger syringes when the syringe pump is acutely lowered or elevated.

Although a change of $130 \mathrm{~cm}$ in the syringe pump height is rare in clinical practice, it clearly demonstrates the impact of syringe size and infusion rate on zero-drug delivery time (Figure 2 ) and infusion bolus. Lowering the infusion pump with the $50 \mathrm{ml}$ syringe in combination with low infusion rates (1.0 or 0.5 $\mathrm{ml} \cdot \mathrm{hr}^{-1}$ ) resulted in clinically relevant zero-drug delivery times exceeding the half-lives of several catecholamines. This can result in serious hemodynamic instability when inotropic agents or vasopressors are used. $^{6}$ Elevation of the pump was associated with potentially relevant additional infusion boluses of up to $0.166 \mathrm{ml}$, resulting in unintended spells of increased blood pressure (Table). Due to these changes in blood pressure, the immature brain may be at risk of cerebral hemorrhage. ${ }^{9}$

A clinically realistic, moderate, vertical displacement of just $50 \mathrm{~cm}$ at an infusion rate of $1 \mathrm{ml} \cdot \mathrm{hr}^{-1}$ resulted in a zero-drug delivery time of five minutes. Such vertical displacements are common, e.g. in preparation of the patient for transport, but should be avoided. Post hoc analysis showed a linear correlation between vertical displacement and delay in drug delivery. The estimated zero-drug delivery time per $10 \mathrm{~cm}$ of displacement using a $50 \mathrm{ml}$ syringe amounts to one minute at an infusion rate of $1 \mathrm{ml} \cdot \mathrm{hr}^{-1}$ and to approximately two minutes at a rate of $0.5 \mathrm{ml} \cdot \mathrm{hr}^{-1}$. At an infusion rate of $0.5 \mathrm{ml} \cdot \mathrm{hr}^{-1}$, every $10 \mathrm{~cm}$ of vertical displacement of a $50 \mathrm{ml}$ syringe is associated with approximately two minutes of zero-drug delivery time or an infusion bolus of $13 \mu \mathrm{l}$.

Flow variabilities due to vertical syringe displacement can be reduced or minimized by using syringes containing less volume Figure 2; Table). However, a $10 \mathrm{ml}$ syringe has to be replaced more often than a 50 $\mathrm{ml}$ syringe, which can be left in the pump for $48 \mathrm{hr}$ of continuous drug administration. Furthermore, only a few modern syringe pumps can be used in combination with small syringes.

Infusion rates of $1 \mathrm{ml} \cdot \mathrm{hr}^{-1}$, and higher, reduced zero-drug delivery time in all syringe sizes (Table) and should be used when highly concentrated, potent drugs are administered by syringe pumps. However, as mentioned before, these higher rates are not always 
appropriate in neonatal or pediatric anesthesia and critical care. In contrast to drug delivery delay, the infusion rate had no influence on infusion bolus, which can only be reduced by the use of smaller syringes.

In addition, it is very important to note that Hagen-Poiseuille's law comes into play when several drugs are administered through a single lumen. Despite leaving the level of the infusion pump delivering the highly potent vasoactive drug unchanged, low ering or elevating of any syringe pump connected to the same catheter lumen may cause a zero-flow condition or infusion bolus of the potent drug. Thus, when administering potent drugs by means of the standard $50 \mathrm{ml}$ syringe, infusion rates $<1 \mathrm{ml} \cdot \mathrm{hr}^{-1}$ increase the risks for the patient, particularly when the relative level of any infusion pump connected to the same catheter lumen is altered.

Approximated syringe compliance and zero-drug delivery time showed an almost linear relation (Pearson's $r=0.97, P<0.001$ ), indicating that internal syringe compliance is the major source of the observed aspiration bolus and zero-drug delivery times. Syringe compliance was closely related to the area of the plunger, which appeared to be the major source of the internal syringe compliance (linear regression $\left.\mathrm{R}^{2}=0.93, P<0.001\right)$. The compressibility of the rubber seal in the syringe plunger due to hydrostatic pressure (Figure 4) causes an increased internal syringe volume resulting in gravitational siphoning during lowering the syringe pump and vice versa.

The limitation of this study is that syringes from other manufacturers were not investigated. The plunger design of other syringes may differ from the products investigated, giving rise to larger compliance with even longer zero-flow periods or to lower compliance with enhanced protection against the effects of vertical syringe pump displacement.

\section{Conclusion}

Vertical displacement of infusion pumps causes clinically relevant flow irregularities, which correlate with the syringe size and infusion rate. Extreme vertical maneuvering of any syringe pump connected to the same catheter lumen should be strictly avoided. Where possible, infusion rates $\geq 1 \mathrm{ml} \cdot \mathrm{h}^{-1}$ and low-compliant, small syringes are recommended when highly potent vasoactive drugs are administered.

\section{Acknowledgments}

We would like to thank René Bolz and Roger Ammann (Medical Technicians) for their technical support.
References

1 Schulze KF, Graff M, Schimmel MS, Schenkman A, Rohan P. Physiologic oscillations produced by an infusion pump. J Pediatr 1983; 103: 796-8.

2 Capes DF, Dunster KR, Sunderland VB, McMillan D, Colditz PB, McDonald C. Fluctuations in syringepump infusions: association with blood pressure variation in infants. Am J Health-Syst Pharm 1995; 52: 1646-53.

3 Klem SA, Farrington JM, Leff RD. Influence of infusion pump operation and flow rate on hemodynamic stability during epinephrine infusion. Crit Care Med 1993; $21:$ 1213-7.

4 Rooke GA, Bowdle TA. Syringe pumps for infusion of vasoactive drugs: mechanical idiosyncrasies and recommended operating procedures. Anesth Analg 1994; 78 : $150-6$.

5 Lönnqvist PA, Löfqvist B. Design flaw can convert commercially available continous syringe pumps to intermittent bolus injectors. Intensive Care Med 1997; 23: 998-1001.

6 Krauskopf K-H, Rauscher J, Brandt L. Influence of hydrostatic pressure on continous application of cardiovascular drugs with syringe pumps. (German) Anaesthesist 1996; 45: 449-52.

7 Leff RD, True WR, Roberts RJ. A gravimetric technique for evaluating flow continuity from two infusion devices. Am J Hosp Pharm 1987; 44: 1388-91.

8 Kim DW, Steward DJ. The effect of syringe size on the performance of an infusion pump. Paediatr Anaesth 1999; 9: 335-7.

9 Funato $M$, Tamai $H$, Noma $K$, et al. Clinical events in association with timing of intraventricular hemorrhage in preterm infants. J Pediatr 1992; 121: 614-9. 